\title{
Understanding the hydrogeology and surface flow in the Cuatrociénegas Basin (NE Mexico) using stable isotopes
}

\author{
Nicholas J Felstead $^{1 *}$, Melanie J Leng ${ }^{2,3}$, Sarah E Metcalfe ${ }^{4}$, Silvia Gonzalez ${ }^{1}$ \\ ${ }^{1}$ School of Natural Sciences and Psychology, Liverpool John Moores University, Liverpool, L3 \\ 3AF, UK \\ ${ }^{2}$ Centre for Environmental Geochemistry, School of Geography, University of Nottingham, \\ Nottingham, Nottingham, NG7 2RD, UK \\ ${ }^{3}$ NERC Isotope Geosciences Facilities, British Geological Survey, Nottingham, NG12 5GG, UK \\ ${ }^{4}$ School of Geography, University of Nottingham, Nottingham, NG7 2RD, UK
}

*Address correspondence: Nicholas Felstead, Department of Geography, Swansea University, Singleton campus, Swansea, SA2 8PP. Email: N.J.Felstead@swansea.ac.uk.

\section{Author contributions:}

Nicholas Felstead - participated in field sampling for isotopic analysis, interpretation of data and is lead contributor to the article and its preparation, including all figures and tables.

Melanie J Leng - participated in interpretation of data and article preparation.

Sarah E Metcalfe - participated in field sampling for isotopic analysis and article preparation.

Silvia Gonzalez - participated in field sampling for isotopic analysis and article preparation. 


\section{Abstract}

In this paper we present surface water oxygen $\left(\delta^{18} \mathrm{O}\right)$, hydrogen $(\delta \mathrm{D})$ and inorganic carbon $\left(\delta^{13} \mathrm{C}_{\mathrm{DIC}}\right)$ isotope data to gain a better understanding of the modern day hydrogeology of Cuatrociénegas Basin, a semi-arid region in northeastern Mexico. Our study focuses on 26 water samples collected in March 2008 to investigate: 1) current provenance and flow pathways of surface waters, 2) the use of stable isotopes in identifying water loss and environmental degradation, and 3) human influence on hydrogeology. $\delta^{18} \mathrm{O}$ for Cuatrociénegas water samples ranged from -7.99 to $+4.97 \%$ (mean $-5.23 \pm 3.13 \%$ ), $\delta \mathrm{D}$ from -54.8 to $+0.3 \%$ (mean $-42.4 \pm$ $14.4 \%$ ), and $\delta^{13} \mathrm{C}_{\mathrm{TDIC}}$ from -21.6 to $-9.2 \%$ (mean $-14.3 \pm 3.4 \%$ ). Samples collected progressively away from their respective spring lines display increasing $\delta^{18} \mathrm{O}$ and $\delta \mathrm{D}$ values. Isotope data suggest that where the residence time of the groundwater is long and/or the system is hydrologically open, $\delta^{18} \mathrm{O}$ may not be a reliable indicator of water loss and environmental degradation. Our data suggest the central ciénega (area $\mathrm{W}(\mathrm{b})$ ) is the most viable area for palaeoenvironmental study and long term monitoring is an essential tool in the identification of ecosystem damage and response, allowing for better future management of the complex and fragile CCB ecosystem.

Keywords: Groundwater; Chihuahuan Desert; Semiarid regions; Mexico

\section{Introduction}

Groundwater is the primary water resource in arid/semi-arid zones and it is well established that groundwater flow systems are vital to allowing human populations and other biota to survive (Ragab and Prudhomme, 2002; Hibbs and Darling, 2005; Scanlon et al. 2006; Herczeg and Leaney, 2011). Such spring fed ecosystems can give rise to endemic species of flora and fauna (Crowley and Ivanstoff, 1990; Deacon and Williams, 1991) that can be very fragile. Evaporation from soil in the unsaturated zone and surface waters remain the most influential processes that affect the oxygen isotope $\left(\delta^{18} \mathrm{O}\right)$ and deuterium isotope $(\delta \mathrm{D})$ composition of surface water. If, for example, two or more lakes are joined, evaporative enrichment of $\delta^{18} \mathrm{O}$ and $\delta \mathrm{D}$ in the lake waters increases with distance from the feeder spring (Clark and Fritz, 1997). Tracing the isotopic enrichment of water can be a good indicator of lake water balance and environmental degradation (Allison and Barnes, 1985; Gibson et al., 2002). Understanding the current day 
hydrogeology of a study region is an important aspect in palaeoenvironmental studies, elucidating the response of lake and wetland systems to past and future climate changes (Johnson et al. 1991; Dean et al. 2013).

The Cuatrociénegas Basin (CCB) situated in the Chihuahuan Desert region of Coahuila State, NE Mexico $\left(26^{\circ} \mathrm{N}, 102^{\circ} \mathrm{W}\right)$ (Fig. 1) is a spring-fed system, and alongside Ash Meadows, Nevada, USA, is one of only two remaining fragile desert 


\section{*Figure 1*}

\subsection{Hydrogeology}

Groundwater discharge into CCB is thought to be from prominent N-S faulting of the Sierra San Marcos (Fig. 2), with fractures that penetrate the regional Cupido-Aurora carbonate aquifer of northeastern Mexico (Lesser and Lesser, 1988; Lehmann et al. 1999; Wolaver et al., 2013). The early conceptual flow models suggested the dominant groundwater flow through the CupidoAurora aquifer is in an easterly direction, towards the Gulf coastal plain region, after recharging in the high Sierra Madre Oriental mountain range (Lesser and Lesser, 1988). However, subsequent studies elucidate more complex regional hydrogeology; in particular, there is the likelihood of additional recharge from farther afield to the north, south and west, that all contribute to observed discharge in the CCB (Johannesson et al.2004; Evans, 2005; Rodriguez et al., 2005; Wolaver et al., 2008; Fig. 1).

Over 200 springs, seeps, ponds, pools (pozas), lakes (lagunas) and rivers (rios) are documented in the CCB (Minckley and Cole, 1968; Minckley, 1969; Minckley, 1992; Badino et al. 2004). Previous geochemical studies suggest that waters issuing along the western springline of the Sierra San Marcos are consistent with fluids associated with the Cupido-Aurora aquifer (Wolaver et al., 2013), with evidence of evaporative through-flow between water bodies (Johannesson $e t$ $a l ., 2004)$. Waters issuing along the eastern springline of the Sierra San Marcos are thought to be a mixture of Cupido-Aurora aquifer and local mountain recharge water (Wolaver et al., 2013), with isolated spring systems associated with local mountain recharge at the base of Sierras La Purisma (Rodriguez et al., 2005) and La Madera (Johannesson et al., 2004; Rodriguez et al., 2005). The majority of the water bodies flow through marsh areas (ciénegas), however some pools are marginal endorheic or seasonally ephemeral, although these are most commonly found in the central eastern area of the basin (Minckley, 1969; Badino et al. 2004; Evans, 2005).

\subsection{Human activity and groundwater impact}

Extraction of surface and groundwater within the CCB for agricultural irrigation, sanitation and drinking has been in operation since the early 1900s (Minckley, 1969), in particular through canals such as the Saca Salada (1902, $80 \mathrm{~km}, \sim 970$ 1/s), the Becerra (1966, $25 \mathrm{~km}, \sim 580$ 1/s), and the Santa Tecla (1966, 53 km, 200 1/s) (Fig. 2). Since the 1960s, human water exploitation 
within the CCB has intensified with a three-fold increase in irrigated agriculture (Minckley, 1992), with canal outflow discharge currently estimated to be approximately $5.3 \times 10^{7} \mathrm{~m}^{3} / \mathrm{yr}$ (Wolaver et al. 2008). In addition to this, large scale groundwater pumping of $7.7 \times 10^{7} \mathrm{~m}^{3} / \mathrm{yr}$ (Lesser, 2001) for irrigation of c. 4,000 hectares of pastureland, occurs in the neighbouring Ocampo and Hundido basins, north and west respectively (Fig. 1). The extraction of a combined $1.3 \times 10^{8} \mathrm{~m}^{3} / \mathrm{yr}$ of groundwater from the region is thought to have contributed to water level declines throughout the CCB in the past 40 years, and caused the complete drying up of Laguna Grande (Fig. 2) in 2009 according to the Comisión Nacional de Áreas Naturales Protegidas (CONANP) (CONANP, pers. comm., January 2010). Recent estimates also indicate a 1m/yr drop in the water table levels of the surrounding basins since extraction began (Wolaver et al. 2013).

Estimates of spring discharge in the CCB are basic (calculations are based on discharge from 1-2 water sources) but are lower than those of regional extraction, ranging from approximately $3.5 \mathrm{x}$ $10^{7} \mathrm{~m}^{3} / \mathrm{yr}$ to $1.26 \times 10^{8} \mathrm{~m}^{3} / \mathrm{yr}$ (Johannesson et al., 2004; Wolaver et al., 2008). This is compounded by basin wide potential evapotranspiration (PET) in the region of $2.8 \times 10^{9} \mathrm{~m}^{3} / \mathrm{yr}$, or $2000 \mathrm{~mm} / \mathrm{yr}$ (Johannesson et al. 2004). Modern PET being an order of magnitude higher than spring discharge alone suggests a significant component of CCB groundwater is as of yet unaccounted for, highlighting the importance of greater understanding of the CCB hydrogeology.

\section{*Figure 2*}

\section{Methods}

Water samples were collected for $\delta^{18} \mathrm{O}, \delta \mathrm{D}$ and $\delta^{13} \mathrm{C}_{\mathrm{TDIC}}$ analysis in March 2008 (dry season) from 15 pools, 3 springs, 2 lakes, 2 rivers, 2 streams, and 2 salt pools (Fig. 2). Water samples were collected using $250 \mathrm{ml}$ polyethylene terephthalate plastic bottles from the epilimnion (>30 $\mathrm{cm}$ below the air-water interface). Wet season samples were not collected as we were not able to conduct a summer field season, although it is assumed wet season flooding events would lead to lower isotope ratios ('amount effect') (Clark and Fritz, 1997). Due to equipment failure during the sampling, we were unable to collect water temperature data. Where published temperature data are not available, qualitative assessments of water body temperature ranges were made onsite in conjunction with CONANP rangers. Therefore, temperature data are presented as three 
range categories: hot $\left(>26^{\circ} \mathrm{C}\right)$, ambient $\left(20-25^{\circ} \mathrm{C}\right)$ and cool $\left(<20^{\circ} \mathrm{C}\right)$. Although, where possible, published water temperature data have been used to categorise the water temperatures (i.e.

Badino et al. 2004; Johannesson et al. 2004). For full analytical methodology please see online supplementary materials.

Table 1: Summary of sampled sub-regions in the Cuatrociénegas Basin.

Sampling sub-region (Fig. 2)

Area W(a)

Area $\mathrm{W}(\mathrm{b})$

Area $E(b)$
Hypothesised flow systems

Churince system (Minckley, 1969;

Evans, 2005)

Garabatal-Becerra-Rio system (Minckley, 1969; Evans, 2005)

Anteojo system (Evans, 2005)

Tio Candido-Hundidos system (Evans, 2005; Wolaver et al, 2006; 2013)

Las Playitas (Minckley, 1969)

\section{Sub-region description}

A mixture of hot pools and a cool lake (Laguna Grande) in close proximity to the fault zone of the Sierra San Marcos, the main discharge zone of the CupidoAurora aquifer in the CCB (Johannesson et al. 2004; Wolaver et al. 2013)

A mixture of hot pools, ambient pools and rivers, and cool pools centred around the ciénega (marsh) area of the piedmont of the Sierra San Marcos y Pinos, an important archaeological area of the CCB (Gonzalez et al. 2007; Felstead et al. 2014)

Cool pools close to the east of the Sierra San Marcos y Pinos (Poza Quintero, Poza Pronatura and Los Hundidos), a region associated with an eastern spring line (Wolaver et al. 2006; 2013).

Cool endorheic and seasonally ephemeral pools in the centre of the eastern basin of the CCB (Las Salinas and Charco Rojo)

Sampling was focused on waters issuing from the Sierras San Marcos and Madera due to these areas being most exploited through pumping and canalization (Minckley, 1992; Evans, 2005; Rodriguez et al., 2005). Four sub-regions (Areas Wa, Wb, Ea, Eb) were sampled to give an overall view of the $\mathrm{CCB}$, focusing on both basin floor high and low points, prominent groundwater discharge zones and areas of socio-economic importance, and are summarized in Table 1. Waters issuing from the western springline (Fig. 2) and high discharge springs in the CCB support the wetland ecosystem located around the piedmont of the Sierra San Marcos, and are the same as those used to irrigate farms in the region (Wolaver et al. 2013). Thus, areas W(a) and (b) were of particular importance due to their proximity to the western springline of the 
Sierra San Marcos and recent suggestions that these areas are most at risk of environmental degradation (Souza et al. 2012).

\begin{tabular}{|c|c|c|c|c|c|c|c|}
\hline Location & $\begin{array}{l}\text { Area/Code } \\
\text { (Fig.2) }\end{array}$ & Date & Lat $\left(\mathbf{N}^{\circ}\right) /$ Long $\left(\mathbf{W}^{\circ}\right)$ & $\begin{array}{c}\text { Temp } \\
\left({ }^{\circ} \mathbf{C}\right)\end{array}$ & $\begin{array}{c}\delta^{18} O \\
(\%)\end{array}$ & $\begin{array}{c}\delta D \\
(\%)\end{array}$ & $\delta^{13} C_{\text {TDIC }}(\%)$ \\
\hline $\begin{array}{l}\text { Poza } \\
\text { Anteojo }\end{array}$ & $\mathrm{W}(\mathrm{b}) / \mathrm{A}$ & $12 / 3 / 2008$ & $26^{\circ} 58^{\prime} 04.58^{\prime \prime} / 102^{\circ} 07^{\prime} 38.22^{\prime \prime}$ & $26.2^{\mathrm{a}}$ & $\begin{array}{l}-7.99 \\
-8.2^{\mathrm{a}}\end{array}$ & $\begin{array}{l}-54.8 \\
-52^{\mathrm{a}}\end{array}$ & -15.7 \\
\hline $\begin{array}{l}\text { Poza } \\
\text { Churince }\end{array}$ & $\mathrm{W}(\mathrm{a}) / \mathrm{PC}$ & $11 / 3 / 2008$ & $26^{\circ} 50^{\prime} 24.76^{\prime \prime} / 102^{\circ} 08^{\prime} 02.40^{\prime \prime}$ & $32^{\mathrm{b}}$ & -6.92 & -50.3 & -19.8 \\
\hline San Marcos & $\mathrm{W}(\mathrm{a}) / \mathrm{SM}$ & $11 / 3 / 2008$ & $26^{\circ} 48^{\prime} 22.51^{\prime \prime} / 102^{\circ} 09^{\prime} 23.08^{\prime \prime}$ & $>26$ & -6.68 & -49.6 & $\ldots$ \\
\hline $\begin{array}{l}\text { Poza } \\
\text { Becerra }\end{array}$ & $\mathrm{W}(\mathrm{a}) / \mathrm{B}$ & $11 / 3 / 2008$ & $26^{\circ} 52^{\prime} 42.98^{\prime \prime} \prime 102^{\circ} 08^{\prime} 17.27^{\prime \prime}$ & $32.4^{\mathrm{a}}$ & $\begin{array}{l}-6.63 \\
-6.7^{\mathrm{a}}\end{array}$ & $\begin{array}{l}-48.9 \\
-48^{\mathrm{a}}\end{array}$ & $\cdots$ \\
\hline $\begin{array}{l}\text { Laguna } \\
\text { Churince }\end{array}$ & $\mathrm{W}(\mathrm{a}) / \mathrm{LC}$ & $11 / 3 / 2008$ & $26^{\circ} 50 ’ 54.00^{\prime} " / 102^{\circ} 08^{\prime} 30.03 "$ & $>26$ & -5.71 & -45.3 & -15.1 \\
\hline $\begin{array}{l}\text { Laguna } \\
\text { Grande }\end{array}$ & $\mathrm{W}(\mathrm{a}) / \mathrm{LG}$ & $11 / 3 / 2008$ & $26^{\circ} 51^{\prime} 09.51^{\prime \prime} / 102^{\circ} 09^{\prime} 05.15^{\prime}$ & $<20$ & +1.17 & -10.0 & -13.9 \\
\hline $\begin{array}{l}\text { Poza } \\
\text { Garabatal }\end{array}$ & $\mathrm{W}(\mathrm{b}) / \mathrm{G}$ & $12 / 3 / 2008$ & $26^{\circ} 53^{\prime} 42.71^{\prime \prime} / 102^{\circ} 08^{\prime} 42.02^{\prime \prime}$ & $18.6^{\mathrm{a}}$ & $\begin{array}{l}-6.58 \\
-6.4^{\mathrm{a}}\end{array}$ & $\begin{array}{l}-47.9 \\
-46^{\mathrm{a}}\end{array}$ & -17.6 \\
\hline Poza Azul & $\mathrm{W}(\mathrm{b}) / \mathrm{Az}$ & $13 / 3 / 2008$ & $26^{\circ} 55^{\prime} 21.41^{\prime \prime} / 102^{\circ} 07^{\prime} 20.84^{\prime \prime}$ & $31^{\mathrm{b}}$ & -6.51 & -48.0 & -13.2 \\
\hline Mex 30-1 & $\mathrm{W}(\mathrm{b}) / 30-1$ & $12 / 3 / 2008$ & $26^{\circ} 53^{\prime} 42.65^{\prime} / 102^{\circ} 08^{\prime} 31.57^{\prime \prime}$ & $20-25$ & -6.37 & -48.7 & -12.4 \\
\hline $\begin{array}{l}\text { Poza Juan } \\
\text { Santos }\end{array}$ & $\mathrm{W}(\mathrm{b}) / \mathrm{JS}$ & $12 / 3 / 2008$ & $26^{\circ} 533^{\prime} 52.00 " / 102^{\circ} 08^{\prime} 53.82^{\prime \prime}$ & $26.7^{\mathrm{a}}$ & $\begin{array}{l}-6.35 \\
-6.4^{\mathrm{a}}\end{array}$ & $\begin{array}{l}-47.5 \\
-46^{\mathrm{a}}\end{array}$ & -11.1 \\
\hline Palm Spring & $\mathrm{W}(\mathrm{b}) / \mathrm{PS}$ & $12 / 3 / 2008$ & $26^{\circ} 54^{\prime} 27.71 ” / 102^{\circ} 09^{\prime} 24.41^{\prime \prime}$ & $<20$ & -6.34 & -47.1 & -9.2 \\
\hline $\begin{array}{l}\text { Rio } \\
\text { Mesquites }\end{array}$ & $\mathrm{W}(\mathrm{b}) / \mathrm{RM} 1$ & $13 / 3 / 2008$ & $26^{\circ} 55^{\prime} 14.53 ” / 102^{\circ} 08^{\prime} 21.31^{\prime \prime}$ & $20-25$ & -6.27 & -48.3 & -21.6 \\
\hline Poza Azul II & $\mathrm{W}(\mathrm{b}) / \mathrm{AzII}$ & $13 / 3 / 2008$ & $26^{\circ} 55^{\prime} 47.60^{\prime \prime} / 102^{\circ} 07^{\prime} 30.35^{\prime \prime}$ & $20-25$ & -6.24 & -47.1 & -10.8 \\
\hline Poza Azul I & $\mathrm{W}(\mathrm{b}) / \mathrm{Az} \mathrm{I}$ & $13 / 3 / 2008$ & $26^{\circ} 55^{\prime} 52.82^{\prime \prime} / 102^{\circ} 07^{\prime} 28.28^{\prime \prime}$ & $20-25$ & -6.16 & -47.0 & -14.7 \\
\hline $\begin{array}{l}\text { Rio } \\
\text { Mesquites } 2\end{array}$ & $\mathrm{~W}(\mathrm{~b}) / \mathrm{RM} 2$ & $12 / 3 / 2008$ & $26^{\circ} 55^{\prime} 23.11^{\prime \prime} / 102^{\circ} 07^{\prime} 06.48^{\prime \prime}$ & $20-25$ & -6.14 & -45.7 & -11.8 \\
\hline Bone Site & $\mathrm{W}(\mathrm{b}) / \mathrm{BS}$ & $12 / 3 / 2008$ & $26^{\circ} 54^{\prime} 59.46 " / 102^{\circ} 07^{\prime} 19.13 ”$ & $<20$ & -6.13 & -46.3 & -13.4 \\
\hline Fast Stream & $\mathrm{W}(\mathrm{b}) / \mathrm{FS}$ & $13 / 3 / 2008$ & $26^{\circ} 54^{\prime} 46.38^{\prime \prime} / 102^{\circ} 09^{\prime} 41.42^{\prime \prime}$ & $<20$ & -5.84 & -45.3 & -10.0 \\
\hline Yucca Pond & $\mathrm{W}(\mathrm{b}) / \mathrm{YP}$ & $13 / 3 / 2008$ & $26^{\circ} 54^{\prime} 45.89^{\prime \prime} / 102^{\circ} 09^{\prime} 13.89^{\prime \prime}$ & $<20$ & -5.79 & -45.1 & -10.2 \\
\hline Rim Pond & $\mathrm{W}(\mathrm{b}) / \mathrm{RP}$ & $13 / 3 / 2008$ & $26^{\circ} 54^{\prime} 38.16^{\prime \prime} / 102^{\circ} 09^{\prime} 38.48^{\prime \prime}$ & $<20$ & -5.75 & -45.5 & -18.8 \\
\hline Mex 30-2 & $\mathrm{W}(\mathrm{b}) / 30-2$ & $12 / 3 / 2008$ & $26^{\circ} 54^{\prime} 19.04 " / 102^{\circ} 09^{\prime} 12.56^{\prime \prime}$ & $20-25$ & -5.75 & -45.2 & -10.4 \\
\hline $\begin{array}{l}\text { Poza Tierra } \\
\text { Blanca }\end{array}$ & $\mathrm{W}(\mathrm{b}) / \mathrm{TB}$ & $12 / 3 / 2008$ & $26^{\circ} 54^{\prime} 38.24^{\prime \prime} / 102^{\circ} 09^{\prime} 10.20^{\prime \prime}$ & $<20$ & -5.68 & -44.5 & -18.0 \\
\hline $\begin{array}{l}\text { Poza } \\
\text { Quintero }\end{array}$ & $\mathrm{E}(\mathrm{a}) / \mathrm{Q}$ & $13 / 3 / 2008$ & $26^{\circ} 51^{\prime} 09.31 " / 102^{\circ} 03^{\prime} 09.70 "$ & $<20$ & -6.84 & -50.1 & -13.3 \\
\hline $\begin{array}{l}\text { Poza } \\
\text { Pronatura }\end{array}$ & $\mathrm{E}(\mathrm{a}) / \mathrm{P}$ & $13 / 3 / 2008$ & $26^{\circ} 51^{\prime} 47.53 ” / 102^{\circ} 02^{\prime} 31.15^{\prime \prime}$ & $<20$ & -6.80 & -49.4 & -16.2 \\
\hline $\begin{array}{l}\text { Los } \\
\text { Hundidos }\end{array}$ & $\mathrm{E}(\mathrm{a}) / \mathrm{LH}$ & $14 / 3 / 2008$ & $26^{\circ} 51^{\prime} 59.35^{\prime \prime} / 102^{\circ} 01^{\prime} 54.77^{\prime}$ & $<20$ & -5.67 & -44.0 & -14.8 \\
\hline Las Salinas & $\mathrm{E}(\mathrm{b}) / \mathrm{LS}$ & $14 / 3 / 2008$ & $26^{\circ} 54^{\prime} 42.90^{\prime \prime} / 102^{\circ} 00^{\prime} 50.64^{\prime \prime}$ & $<20$ & +2.98 & -2.0 & -17.5 \\
\hline Charco Rojo & $\mathrm{E}(\mathrm{b}) / \mathrm{CR}$ & $14 / 3 / 2008$ & $26^{\circ} 54^{\prime} 53.40^{\prime \prime} / 102^{\circ} 00^{\prime} 33.23 "$ & $<20$ & +4.97 & +0.3 & $\ldots$ \\
\hline
\end{tabular}




\section{Results}

\subsection{Oxygen and hydrogen isotopes}

$\delta^{18} \mathrm{O}$ and $\delta \mathrm{D}$ data for the 26 locations (Fig. 2 ) in the CCB are presented in Table 2 and are plotted on Figure 3a alongside the Global Meteoric Water Line (GMLW, Craig, 1961) and Local Evaporation Lines (LEL) from the CCB (Johannesson et al. 2004; Rodriguez et al. 2005). $\delta^{18} \mathrm{O}$ and $\delta \mathrm{D}$ values of seasonally weighted groundwater (indicative of precipitation values) in the CCB are $-8.3 \%$ and $-55.8 \%$ respectively (Wassenaar et al. 2009), although no meteoric water line is available for the CCB (Johannesson et al. 2004;). However, the Local Meteoric Water Line (LMWL) from Chihuahua (Cortés et al. 1997) is used here due to Chihuahua receiving precipitation from the same atmospheric moisture sources as the CCB: summer Gulf of Mexico monsoon and winter 'nortes' (Johannesson et al. 2004).

All of the isotope data from our samples plot to the right of the GMWL and the LMWL (Fig. 3a). Of the 26 samples, 22 of them are grouped together with $\delta^{18} \mathrm{O}$ and $\delta \mathrm{D}$ values of the water ranging from $-6.92 \%$ to $-5.67 \%$ and $-50.3 \%$ and $-44 \%$ respectively. A linear regression line through the data $(n=26)$ (Fig. 3a) indicates a LEL defined by equation: $\delta \mathrm{D}=4.5 \delta^{18} \mathrm{O}-19$. The samples plot within the range reported for the CCB previously (Johannesson et al. 2004; Rodriguez et al., 2005) The slope of 4.5 is lower than that of both Johannesson et al. (2004) and Rodriguez et al. (2005), with slopes of 4.9 and 5.15 respectively.

The LEL shows a high linear correlation between $\delta^{18} \mathrm{O}$ and $\delta \mathrm{D}\left(\mathrm{R}^{2}=0.99\right)$ and extrapolation back to the LMWL gives a hypothetical meteoric water value of $-8.4 \%$ and $-57 \%$ for $\delta^{18} \mathrm{O}$ and $\delta \mathrm{D}$ respectively.

\section{*Figure 3*}

\subsubsection{Area $W(a)$}

The five water samples in this sub-region range from $-6.92 \%$ (Poza Churince) to $+1.17 \%$ (Laguna Grande) and $-50.3 \%$ and $-10 \%$ for $\delta^{18} \mathrm{O}$ and $\delta \mathrm{D}$ respectively. Laguna Grande appears to be anomalous as it is the only sample to display a positive $\delta^{18} \mathrm{O}$ value in areas $\mathrm{W}(\mathrm{a}), \mathrm{W}(\mathrm{b})$ and $\mathrm{E}$ (a) and also the only sample with a temperature of $<20^{\circ} \mathrm{C}$ in $\mathrm{W}$ (a). 


\subsubsection{Area $W(b)$}

The 16 water samples in this sub-region range from $-7.99 \%$ (Poza Anteojo) to $-5.68 \%$ (Poza Tierra Blanca) and $-54.8 \%$ to $-44.5 \%$ for $\delta^{18} \mathrm{O}$ and $\delta \mathrm{D}$ respectively. Poza Anteojo water plots very closely to the intersection of the GMWL and LMWL. The data indicate two flow paths through $\mathrm{W}(\mathrm{b})$ : 1 ) waters showing $\delta^{18} \mathrm{O}$ enrichment from $-6.58 \%$ to $-6.14 \%$ around the piedmont (PG, 30-1, JS, PS, 30-2, RMI, AzII, AzI, Az, RM2) (Fig. 2), and 2) low temperature waters showing $\delta^{18} \mathrm{O}$ enrichment from $-6.13 \%$ to $-5.68 \%$ through the ciénega area (BS, FS, YP, RP, TB) (Fig. 2).

\subsubsection{Area $E(a)$}

There are three water samples in this sub-region, ranging from $-6.84 \%$ (Poza Quintero) to $5.67 \%$ (Los Hundidos) and $-50.1 \%$ to $-44 \%$ for $\delta^{18} \mathrm{O}$ and $\delta \mathrm{D}$ respectively. These three samples progressively enrich in ${ }^{18} \mathrm{O}$ towards area $\mathrm{E}(\mathrm{b})$ (Table 2, Figs. 2 and 3a).

\subsubsection{Area $E(b)$}

The two water samples in this sub-region (Las Salinas and Charco Rojo) both have positive $\delta^{18} \mathrm{O}$ values of $+2.98 \%$ and $+4.97 \%$ respectively, and $\delta \mathrm{D}$ values of $-2 \%$ and $+0.3 \%$ respectively. Both areas $\mathrm{W}(\mathrm{b})$ and $\mathrm{E}(\mathrm{a})$ display $\delta^{18} \mathrm{O}$ enrichment east towards area $\mathrm{E}(\mathrm{b})$ (Table 2, Figs. 2 and 3a).

\subsection{Carbon isotopes}

$\delta^{13} \mathrm{C}_{\text {TDIC }}$ data for the 26 locations in the CCB are presented in Table 2 and are plotted against $\delta^{18} \mathrm{O}$ in Figure 3b. Pozas San Marcos, Becerra and Charco Rojo did not contain sufficient amounts of bicarbonate for $\delta^{13} \mathrm{C}_{\mathrm{TDIC}} . \delta^{13} \mathrm{C}_{\mathrm{TDIC}}$ values range from $-21.6 \%$ (Rio Mesquites 1 ) to 9.2\% (Palm Spring).

\section{Discussion}

The GMWL is based on precipitation data from around the world (Craig, 1961). Deviations away from the GMWL, in the form of a LMWL or LEL, are comprised of a sample set of local sites, specific to one region. Extrapolation of these lines back to the intersection with the GMWL indicates the isotope composition of the precipitation source for that set of local sites (Clark and 
Fritz, 1997). The intersection of the GMWL, LMWL and LEL at $-8.4 \%$ ( $\left(\delta^{18} \mathrm{O}\right)$ and $-57 \%$ ( $\left.\delta \mathrm{D}\right)$ (Fig. 3a) coincident with the isotope composition of seasonally weighted groundwater (Wassenaar et al. 2009) suggests a common precipitation source for the CCB regional groundwater. The position of our samples to the right of the GMWL and LMWL indicates that they have undergone varying degrees of evaporative enrichment, defining the LEL with a slope of 4.5 (Fig. 3a), this is consistent with Evans (2005) suggestion that evaporation is the main reason for water loss in the basin.

The main thermal springs in the CCB (Poza Anteojo and Becerra) have undergone least evaporation (Table 2) and are categorised as low evaporation end members (Evans, 2005). The $\delta^{18} \mathrm{O}$ and $\delta \mathrm{D}$ values for Poza Anteojo (-7.99\%o, -54.8\%o) closely match seasonally weighted modern precipitation for the CCB (Wassenaar et al. 2009), whereas isotope values for Poza Becerra $(-6.63 \%$, $-48.9 \%$ ) are higher (Table 2) suggesting that Poza Anteojo water is sourced from groundwater different to that of systems arising from Sierra San Marcos groundwater, as suggested by Johannesson et al. (2004). Recharge elevation has been suggested as a reason for these differences (Johannesson et al. 2004; Rodriguez et al. 2005) with estimates in the region of $-0.48 \%$ o $/ 100 \mathrm{~m}$ for $\delta^{18} \mathrm{O}$ (Rodriguez et al. 2005). However, residence times $>60 \mathrm{yr}$ (Wolaver et al. 2013) and the well mixed nature of the CCB groundwater indicated by adherence to the LEL (Fig. 3a) suggests that recharge elevation estimates may be inaccurate (Blasch and Bryson, 2007).

Karst flow is often not straightforward in the CCB (Evans, 2005; Piccini et al. 2007) although distinct flow systems for the CCB have been previously hypothesised (Minckley, 1969; Evans, 2005, Table 1). Based on our results and CCB topography, we suggest four hydrologic systems in the CCB: 1) A high water temperature system probably independent from the other aquifers e.g. Poza Anteojo; 2) High water temperature, but also an evaporative through-flow system discharging at the western base of the Sierra San Marcos y Pinos (Fig. 2); 3) A low water temperature, evaporative through-flow system discharging on the eastern base of the Sierra San Marcos y Pinos (Fig. 2); and 4) low water temperature endorheic system resulting from the termination of hydrologic systems 2 and 3 . These systems are broadly consistent with previously hypothesised systems and are further discussed below:

\subsection{Current provenance and surface flow pathways of CCB waters}




\subsubsection{Poza Anteojo system}

Poza Anteojo in area W(b) (Fig. 2) could be sourced directly from the limestone karst system, arising from Sierra Madera, but the warm temperature of the water $\left(26.2^{\circ} \mathrm{C}\right.$ reported by Johannesson et al. (2004)), is higher than the CCB average mean annual air temperature of $21.2^{\circ} \mathrm{C}$ (Badino et al. 2004) suggesting that Poza Anteojo water has a component of deep thermal water (e.g. focused channel recharge (Blasch et al. 2008)). Tritium values reported by Wolaver $e t$ al. (2013) indicate a long residence time of >60 years for water at this site. This residence time along with low conductivity and high carbonate concentrations (Evans, 2005) suggests the Poza Anteojo system is independent from the regional groundwater system (Fig. 1) and might also explain the lack of response in $\delta^{18} \mathrm{O}$ and $\delta \mathrm{D}$ to groundwater extraction between sampling in 1999 (Johannesson et al. 2004) and our sampling in 2008. The Sierra Madera karst reservoir feeding Poza Anteojo may form a part confined aquifer, with CCB specific recharge/discharge, heated by deep circulation, similar to arid groundwater recharge areas in Arizona and Texas (Kastning, 1983; Hogan et al. 2004; Blasch et al. 2008).

\subsubsection{Churince-Garabatal-Becerra-Rio Mesquites (CGBRM) system}

The prominent hydrologic feature in the CCB is an evaporative through-flow system originating to the west of the basin in area W(a) and flowing east through areas W(b) and E(b), based on evidence of progressive evaporation (Figs. 2 and 3a). Pozas Churince (PC) and Becerra (B) mark the beginning of the system, and their proximity to the western springline suggests waters issuing from these pools are from the Cupido-Aurora aquifer. Again, Wolaver et al. (2013) suggest groundwater of long residence time. Despite having similar isotopic values to both Pozas Churince and Becerra, Poza San Marcos (SM) does not appear to form part of the through-flow system, though it may be linked through sub-surface channels that are prevalent throughout the basin. The thermal waters on the west side of the CCB issue from local faulting (Badino et al. 2004; Johannesson et al. 2004; Evans, 2005), and are of a Ca-SO $\mathrm{SO}_{4}$ type (Winsborough, 1990; Johannesson et al. 2004; Evans, 2005; Wolaver et al. 2013), resulting in gypsum deposition. If these thermal pools were recharged from the surrounding Cretaceous limestone ranges, we would expect the water to have higher $\delta^{18} \mathrm{O}$ values (e.g. Poza Anteojo) and be of a $\mathrm{Ca}-\mathrm{HCO}_{3}$ type, as seen in waters issuing to the east of the Sierra San Marcos y Pinos (Evan, 2005), and more widely in the Sierra Madre Oriental (Rodriguez et al. 2005). Johannesson et al. (2004) note 
the presence of gypsum in the Sierra de la Fragua (see Fig. 2), so the $\mathrm{SO}_{4}$-rich waters might originate there. These pools progressively become $\delta^{18} \mathrm{O}$ enriched along the northern axis of the spring line through area W(a) (Figs. 2 and 3a). The Churince and Becerra systems have previously been hypothesised to be independent from each other (Minckley, 1969; Evans, 2005). However, surface mixing of waters between the pools (dictated by topography) and pools further north along the spring line which are at systematically lower elevations (Poza Churince $745 \mathrm{~m}$ a.s.1; Becerra $741 \mathrm{~m}$ a.s.l), and are progressively more evaporated, suggest these two systems are linked by surface and/or sub-surface channels.

As the Churince-Garbatal-Becerra-Rio Mesquites system reaches the piedmont of the Sierra San Marcos (Area W(b), Fig. 2) the flow pattern across the CCB becomes a complex mix of cold and ambient surface, ambient subterranean and thermal groundwater flow (Table 2; Figs. 2 and 3a) with significant subterranean exchanges between different flow processes, similar to those observed in ciénegas (marshes) of the Sonoran desert (Minckley and Brunelle, 2007; Minckley et al. 2009). This region of the basin is relatively sheltered from evaporation due to sub-surface channels and mixing of waters (Evans, 2005). The Rio Mesquites drains this area of the basin, flowing towards the terminal system in the east of the CCB (area E(b)), and it becomes hard to ascertain which water bodies mix at this point (Fig. 3a).

\subsubsection{Tio Candido-Hundidos system}

The Tio Candido-Hundidos system evident in the CCB originates on the east side of the Sierra San Marcos y Pinos at Poza de Quintero $(\mathrm{Q})$ before flowing to Poza Pronatura $(\mathrm{P})$ and towards Los Hundidos (LH) (Fig. 2). The water bodies plot on the LEL, similar to the main through-flow system in Figure 3a. Poza de Quintero $\left(\delta^{18} \mathrm{O}-6.84 \%\right.$ ) has a very similar isotopic composition to that of Pozas Churince and Becerra (Johannesson et al. 2004). However, unlike the hydrothermal water bodies sourced from the Cupido-Aurora aquifer on the western base of the Sierra San Marcos y Pinos, Poza Quintero is a cool water body $\left(<20^{\circ} \mathrm{C}\right)$ and there are no associated gypsum deposits, as with the $\mathrm{Ca}-\mathrm{SO}_{4}$ water issuing from the western spring line. This system may be sourced from local karst reservoir water, consistent with $\mathrm{Ca}-\mathrm{HCO}_{3}$ composition waters reported in previous studies (Minckley and Cole, 1968; Winsborough, 1990; Evans, 2005; Wolaver et al. 2006). Wolaver et al. (2013) record slightly higher tritium values at sites east of the Sierra San Marcos y Pinos consistent with more localised flow and shorter residence time, indicating a third 
groundwater source for the $\mathrm{CCB}$ and possibly a better irrigation abstraction area away from the fragile Churince-Garbatal-Becerra-Rio Mesquites system.

Alluvial fans at the eastern piedmont base of the Sierra San Marcos y Pinos may prevent the circulation of deep, thermal water and no faults are evident in the limestone strata to suggest any direct upwelling (Lesser and Lesser, 1988). It is worth noting that we did not sample further south on the eastern spring line, the origin point of the Santa Tecla Canal (Fig. 2). A limited number of hot water bodies e.g. Poza Escobedo, form on the eastern flank of the Sierra San Marcos through upwelling of hot water where alluvial fans are not located (Badino et al. 2004; Wolaver et al. 2008; 2013). The secondary through-flow system could also form part of a larger, eastern CCB flow system with greater numbers of water bodies, both hot $\left(25^{\circ} \mathrm{C}\right.$ to $\left.35^{\circ} \mathrm{C}\right)$ and $\operatorname{cool}\left(<20^{\circ} \mathrm{C}\right)$.

\subsubsection{Endorheic system}

The two pools - Las Salinas (LS) and Charco Rojo (CR) - forming this system, are very distinctive on Figure 3 and are highly evaporated. Known locally as Las Playitas (meaning little beaches or plains) because of the prevalence of trona and nahcolite evaporates (Badino et al. 2004), area $E(b)$ is the lowest elevation ( $700 \mathrm{~m}$ a. s. 1) area in the CCB and where the ChurinceGarbatal-Becerra-Rio Mesquites and Tio Candido-Hundidos systems terminate. Evans (2005) suggests that the precipitation of gypsum minerals in this region of the basin indicates some Ca$\mathrm{SO}_{4}$ waters may be flowing across the entirety of the CCB from the western springline, although we didn’t observe any such deposits in our study.

\subsubsection{Carbon isotopes}

$\delta^{13} \mathrm{C}_{\mathrm{TDIC}}$ values range from $-21.6 \%$ to $-9.2 \%$ in the 23 measurable water samples in the CCB reflecting different soil and bedrock interactions. Water bodies with lower $\delta^{13} \mathrm{C}_{\mathrm{TDIC}}$ values, in the range of $-22 \%$ o to $-16 \%$ (Table 2 ; Fig. $3 b$ ) probably indicate a greater input/interaction with soil carbon derived from plants and soils. Water bodies with higher $\delta^{13} \mathrm{C}_{\mathrm{TDIC}}$ values, in the range of $16 \%$ to $-9 \%$ (Table 2; Fig 3b), more likely suggest a larger component of groundwater aquifer discharge or input of soil carbon from $\mathrm{C}_{4}$ vegetation which have a higher $\delta^{13} \mathrm{C}$ than $\mathrm{C}_{3}$ plants. It is unlikely that the different degrees of evaporation have much effect on $\delta^{13} \mathrm{C}$ since there is no relationship between $\delta^{18} \mathrm{O}$ and $\delta^{13} \mathrm{C}_{\text {TDIC }}$ (Fig. 3b). 
All of the water bodies in the CCB contain a component of bicarbonate from the limestone aquifers. Bralower et al. (1999) estimate the Cupido-Aurora limestone to have $\delta^{13} \mathrm{C}_{\mathrm{TDIC}}$ values of $+2 \%$ to $+4.5 \%$ which indicates that dissolution of the Cupido-Aurora limestone would result in

${ }^{13} \mathrm{C}$ enriched groundwater. The high temperature Cupido-Aurora aquifer sourced water bodies in the $\mathrm{CCB}$ all have high $\delta^{13} \mathrm{C}_{\mathrm{TDIC}}$ values indicating that the carbon is from a mixture of soil $\mathrm{CO}_{2}$, aquifer dissolution and endogenic sourced carbon (Wolaver et al. 2013).

With the limited data available, it is unclear what these compositional differences mean in terms of the hydrogeology of the basin, although they do highlight the very complex nature and histories of the CCB waters.

\subsection{Water loss, environmental degradation and human impact}

Observed drought and drying of water bodies within the CCB during the period between studies (1999 to 2008) (CONANP, pers. comm. 2010) suggest that PET is increasing and there are compounding problems associated with pumping and large scale water extraction, particularly affecting waters issuing along the western springline of the Sierra San Marcos. The desiccation of Laguna Grande after the 2008 sampling is a clear indicator of this. It is worth noting that our data plot slightly below that of Johannesson et al. (2004) and Rodriguez et al. (2005) (Fig. 3a) with a LEL slope of 4.5 as opposed to 4.9 and 5.15 respectively, indicating possible increasing PET in the basin. However, we recognize that the LEL slope change is small and could be a function of a number of climatic factors, including aridification, the origin of the vapour mass, seasonality of precipitation, evaporation during and after rainfall (Clark and Fritz, 1997).

Despite the observation that ground water levels have been declining, the lack of change in the range of water isotope composition between the previous studies (Johannesson et al. 2004; Rodriguez et al. 2005) and our study (Table 2), suggest the $>60 \mathrm{yr}$ residence time of aquifer water (Wolaver et al. 2013) may be dampening any atmospheric forced change in the surface water geochemistry particularly in the waters not subjected to surface evaporation (e.g. Poza Anteojo, Poza Churince, Poza Becerra). Conversely, high evaporation waters in the terminal east CCB are isotopically modified away from the source water (Fig. 3a). So although the basin overall might be considered to be naturally hydrologically closed, because of its complex internal hydrology, it doesn't behave like a classic closed basin e.g. Smith Creek (Thomas et al. 1989). 
As such, the best areas for monitoring water loss and environmental degradation are between the low and high evaporation end members, possibly in the marsh in area W(b) (Fig. 2). Surface and subterranean flow in this part of the CCB is complex and as such the marsh system may be the most accurate representation of closed basin systematics and consequently, most reliable area for palaeoenvironmental study.

PET effects are evident in all three studies of the CCB surface waters and given the variability in data, vulnerability of the piedmont marsh system to environmental degradation, and socioeconomic importance of the $\mathrm{CCB}$, further study is certainly warranted to understand basin wide evaporative effects and potential for groundwater abstraction from the eastern flow system.

\section{Conclusions}

Isotope data $\left(\delta^{18} \mathrm{O}, \delta \mathrm{D}\right.$ and $\left.\delta^{13} \mathrm{C}_{\mathrm{TDIC}}\right)$ from this study suggest that apart from the drainage canal, the CCB is currently hydrologically closed, with different degrees of surface evaporation probably dependent on residence time in the basin. There is evidence for through-flow between water bodies as they become isotopically evolved due to evaporation. Groundwater discharge in the CCB appears to be a complex mix of hydrothermal groundwater probably originating from a regional aquifer; ambient meteoric karst water; and water originating from a deep lying karst reservoir. All the waters lie on a LEL with a slope of 4.5 indicating evaporation of surface waters is changing the isotopic composition of the CCB surface waters. Water body temperature data indicate that the observed evaporation of the CCB surface water is not related to the temperature of the water sampled, however, the data cohort is small. At least four separate hydrological systems have been identified based on the isotope data described here:

1) An independent system (Poza Anteojo), closely reflecting the isotopic composition of modern precipitation, is consistent with recharge in the Sierra Madera, previously suggested by Johannesson et al. (2004).

2) High temperature groundwater discharge on the western springline of the Sierra San Marcos $(\mathrm{W}(\mathrm{a}))$, flowing through the central ciénega area $(\mathrm{W}(\mathrm{b}))$ towards the terminal east of the basin (E(b)) (primary through-flow system). 
3) Low water temperature, secondary through-flow system is evident on the eastern flank of the Sierra San Marcos y Pinos (area E(a)), suggesting a greater influence of meteoric karst waters.

4) Low water temperature endorheic system where hydrologic systems 2 and 3 (primary and secondary through-flow) terminate.

$\delta^{13} \mathrm{C}_{\mathrm{TDIC}}$ data suggest that the carbon in the CCB is sourced from both aquifer carbonate and soil derived $\mathrm{CO}_{2}$.

Although based on a limited number of common samples, comparison of the isotopic data reported here with that of Johannesson et al. (2004) and Rodriguez et al. (2005) indicates that at sites where the residence time of the groundwater is long and/or the system is hydrologically open, $\delta^{18} \mathrm{O}$ values may not be reliable indicators of water loss and therefore environmental degradation. Our data suggest the area $\mathrm{W}(\mathrm{b})$ is the most viable area for palaeoenvironmental study and long term monitoring is an essential tool in the identification of ecosystem damage and response, allowing for better future management of the complex and fragile CCB ecosystem.

\section{Acknowledgements}

We would like to thank CONANP, Pronatura Noreste A.C. and the residents of the town of Cuatro Ciénegas for facilitating this study. Ivo Garcia Gutierrez, Director of the Área de Protección de Flora y Fauna de Cuatrociénegas (APFFCC), is particularly thanked for his assistance in providing research permits. David Huddart provided assistance in the field. This project was supported by the Natural Environment Research Council (NERC) grant NE/F006772/1 to NJF, as part of his PhD.

\section{References}

Allison, G. B., Barnes, C. J. 1985. Estimation of evaporation from normally “dry" Lake Frome in South Australia. Journal of Hydrology 78, 229-242.

Badino, G., Bernabei, T., De Vivo, A., Giulivo, I., Savino, G. (Eds.). 2004. Under the Desert: The Mysterious Waters of Cuatro Ciénegas, $1^{\text {st }}$ ed. Associazione Geografica La Venta, Treviso, Italy. 
Blasch, K. W., Bryson, J. R. 2007. Distinguishing Sources of Ground Water Recharge by Using $\delta^{2} \mathrm{H}$ and $\delta^{18} \mathrm{O}$. Groundwater 45, 294-308.

Blasch, K. W., Constantz, J., Stonestrom, D. A., 2008. Ground-Water Recharge in the Arid and Semiarid Southwestern United States. USGS Professional Paper 1703, Appendix-1, 353-375.

Bralower, T. J., CoBabe, E., Clement, B., Sliter, W. V., Osburn, C. L., Longoria, J., 1999. The record of global change in Mid-Cretaceous (Barremian-Albian) sections from the Sierra Madre, north-eastern Mexico. The Journal of Foraminiferal Research 29, 418-437.

Clark, I., Fritz, P. 1997. Environmental Isotopes in hydrology. Lewis, Boca Raton, Florida.

Cortés, A., Durazo, J., Farvolden, R. N., 1997. Studies of isotopic hydrology of the basin of Mexico and vicinity: annotated bibliography and interpretation. Journal of Hydrology 198, 346376.

Craig, H., 1961. Isotopic variations in meteoric waters. Science, 133, 1702-1703.

Crowley, L. E. L. M., Ivanstoff, W., 1990. A second hardyhead, Craterocephalusgloveri (Pisces: Atherinidae), from Dalhousie Springs, central Australia. Ichthyological Exploration of Freshwaters 1, 13-122.

Deacon, J. E., Williams, C. D., 1991.Ash Meadows and the legacy of the Devils Hole pupfish. In: Minckley, W. L., Deacon, J. E. (Eds.). Battle Against Extinction: Native Fish Management in the American West. University of Arizona Press, Tucson, pp. 69-87.

Dean, J. R., Jones, M. D., Leng, M. J., Sloane, H. J., Roberts, C. N., Woodbridge, J., Swann, G. E. A., Metcalfe, S. E., Eastwood, W. J., Yiğitbaşıoğlu, H., 2013. Palaeo-seasonality of the last two millennia reconstructed from the oxygen isotope composition of carbonates and diatom silica from Nar Golu, central Turkey. Quaternary Sciences Reviews 66, 35-44.

Díaz, S. C., Therrell, M. D., Stahle, D. W., Cleaveland, M. K. 2002. Chihuahua (Mexico) winterspring precipitation reconstructed from tree-rings, 1647-1992. Climate Research 22, 237-244

Evans, S. B., 2005. Using Chemical Data to Define Flow systems in Cuatro Ciénegas, Coahuila, Mexico. M.Sc. Thesis, University of Texas-Austin, pp. 127. 
Felstead, N. J., Gonzalez, S., Huddart, D., Noble, S. R., Hoffman, D. L., Metcalfe, S. E., Leng, M. J., Albert, B. M., Pike, A. W. G., Gonzalez-Gonzalez, A., Jiménez-López, J. C. 2014. Holocene-aged human footprints from the Cuatrociénegas Basin, NE Mexico. Journal of Archaeological Science 42, 250-259.

Gonzalez, A. H. G., Lockley, M. G., Rojas, C. S., Espinoza, J. L., Gonzalez, S. 2007. Notes on the re-discovery of a 'lost' hominid footprint site from the Cuatro Ciénegas basin (Coahuila), Mexico. New Mexico Museum of Natural History Science Bulletin 54, 11-15.

Gibson, J. J., Prepas, E. E., McEachern, P. 2002. Quantitative comparison of lake throughflow, residency, and catchment runoff using stable isotopes: modelling and resultys from a survey of boreal lakes. Journal of Hydrology 262, 128-144.

Hendrickson, D., Marks, J., Moline, A., Dinger, E., Cohen, A., 2008. Combining ecological research and conservation: A case study in Cuatrociénegas, Mexico. In: Stevens, L., Meretsky, V., (Eds.). Aridland springs in North America. University of Arizona Press, Tucson, pp. 127157.

Herczeg, A. L., Leaney, F. W., 2011. Review: Environmental tracers in arid-zone hydrology. Hydrogeology Journal 19, 17-29.

Hibbs, B. J., Darling, B. K., 2005. Revisiting a classification scheme for U.S.-Mexico alluvial basin-fill aquifers. Groundwater 43, 750-763.

Hogan, J. F., Phillips, F. M., Scanlon, B. R., 2004. Groundwater Recharge in a Desert Environment: The Southwestern United States. American Geophysical Union, Florida, USA.

Johannesson, K. H., Cortés, A., Kilroy, K. C., 2004. Reconnaissance isotopic and hydrochemical study of Cuatro Ciénegas groundwater, Coahuila, Mexico. Journal of South American Earth Sciences 17, 171-180.

Johnson, T. C., Halfman, J. D., Showers, W. J., 1991. Paleoclimate of the past 4000 years at Lake Turkana, Kenya, based on the isotopic composition of authigenic calicite. Palaeogeography, Palaeoclimatology, Palaeoecology 85, 189-198. 
Kastning, E. H., 1983. Relict caves as evidence of landscape and aquifer evolution in a deeply dissected carbonate terrain: Southwest Edwards Plateau, Texas, USA. Journal of Hydrology 61, $89-112$.

Lehmann, C., Osleger, D. A., Montańez, I. P., Sliter, W., Arnaud-Vanneau, A., Banner, J., 1999. Evolution of the Cupido and Coahuila carbonate platforms, early Cretaceous, north-eastern Mexico. Geological Society of America Bulletin 111, 1010-1029.

Lesser, J. M., Lesser, G., 1988.Region 9, Sierra Madre Oriental. In: Back, W., Rosenhein, J. S. and Seaber, P. R. (Eds.). Hydrogeology; The Geology of North America. Geological Society of America, Boulder 2, 89-92.

Lesser y Asociados. 2001. Sinopsis del studio de evaluación hidrogeológica e isotópica en el Valle del Hundido, Coahuila: Comisión Nacional del Agua, Subdirección General Técnica, Gerencia de Aguas Subterráneas, pp. 125.

Metcalfe, S. E. 2006. Late Quaternary Environments of the Northern Deserts and Central Transvolcanic Belt of Mexico. Annals of the Missouri Botanical Gardens 93, 258-273.

Minckley, T. A., Brunelle, A. R., 2007. Palaeohydrology and growth of a desert ciénega. Journal of Arid Environments 69, 420-431.

Minckley, T. A., Clementz, M. T., Brunelle, A., Klopfenstein, G. A., 2009. Isotopic analysis of wetland development in the American Southwest. The Holocene 19, 737-745.

Minckley, W. L.,1969. Environments of the Bolsón of Cuatro Ciénegas, Coahuila, Mexico, with special reference to the aquatic biota. Texas Western Press, University of Texas El Paso Science Series 2, 1-65.

Minckley, W. L., 1992. Three Decades near Cuatro Ciénegas, México: Photographic Documentation and a Plea for Area Conservation. Journal of the Arizona-Nevada Academy of Science26, 81-110.

Minckley, W. L., Cole, G. A., 1968.Preliminary Limnologic Information on Waters of the Cuatro Cienegas Basin, Coahuila, Mexico. The Southwestern Naturalist 13, 421-431. 
Piccini, L., Forti, P., Giulivo, I., Mecchia, M. 2007. The polygenetic caves of Cuatro Ciénegas (Coahuila, Mexico): morphology and speleogenesis. International Journal of Speleology 36, 8392.

Quintanilla, J. A. V., 2001. Listados Florísticos de México: XXIII. Flora de Coahuila. Instituto de Biología, UNAM, México.

Ragab, R., Prudhomme, C., 2002. Climate change and water resources management in arid and semi-arid regions: prospective and challenges for the $21^{\text {st }}$ century. Journal of Biosystems Engineering 81, 3-34.

Rodriguez, A. A. A., Mijares, F. J. A., Ojeda, C. G., Morales, M. M., Hita, L. G., Zamarrón, G. H, Arellano, I. M., González, M. A. M., Flores, G. O., Almanza, P. G., Sánchez, R. L., López, J. L. P., Arzate, G. R., Fritz, P., Espinoza, J.R., 2005. Estudio hidrogeológico de los acuíferos el Hundido y Cuatrociénegas, Coahuila. Jiutepec, Morelos, Mexico: Secretaria de Medio Ambiente y Recursos Naturales, Instituto Mexicano de Tecnología del Agua, Comisión Nacionaldel Agua, Instituto Nacional de Ecologia.

Ryan, W. B. F., Carbotte, S. M., Coplan, J. O., O'Hara, S., Melkonian, A., Arko, R., Weissel, R. A., Ferrini, V., Goodwillie, A., Nitsche, F., Bonczkowski, J., Zemsky, R., 2009. Global MultiResolution Topography synthesis. Geochemistry, Geophysics, Geosystems, doi: 10.1029/2008GC002332.

Scanlon, B. R., Keese, K. E., Flint, A. L., Flint, L. E., Gaye, C. B., Edmunds, W. M., Simmers, I., 2006. Global synthesis of groundwater recharge in semiarid and arid regions. Hydrological Processes 20, 3335-3370.

Schmidt, R. H. Jr., 1986. Chihuahuan Climate. In: Barlow, J. C., Powell, A. M., Timmerman, B. N., (Eds.). Second Symposium on Resources of the Chihuahuan Desert Region U.S. and Mexico. Chihuahuan Desert Research Institute, 40-63.

SEMARNAP. 1996. Programa de Áreas Naturales Protegidas de México 1995-2000. Instituto Nacional de Ecología, México. 
Souza, V., Siefert, J. L., Escalante, A. E., Elser, J. J., Eguiarte, L. E., 2012. The Cuatro Ciénegas Basin in Coahuila, Mexico: An Astrobiological Precambrian Park. Astrobiology 12, 641-647.

Stein, B., Kutner, L., Adams, J., (Eds.). 2000. Precious Heritage: The Status of Biodiversity in the United States. Oxford University Press, Oxford, UK.

Thomas, J. M., Welch, A. H., Preissler, A. M. 1989. Geochemical evolution of ground water in Smith Creek Valley - a hydrologically closed basin in central Nevada, U.S.A. Applied Geochemistry 4, 493-510.

Villanueva-Diaz, J., Stahle, D. W., Luckman, B. H., Cerano-Paredes, J., Therrell, M. D., Cleaveland, M. K., Cornejo-Oviedo, E. 2007. Winter-spring precipitation reconstructions from tree rings for northeast Mexico. Climatic Change 83, 117-131.

Wassenaar, L. I., Van Wilgenburg, S. L., Larson, K., Hobson, K. A., 2009. A groundwater isoscape $\left(\delta \mathrm{D}, \delta^{18} \mathrm{O}\right)$ for Mexico. Journal of Geochemical Exploration 102, 123-136.

Winsborough, B., 1990. Some ecological aspects of modern fresh-water stromatolites in lakes and streams of the Cuatro Ciénegas Basin, Coahuila, Mexico. Ph.D. Thesis, University of TexasAustin, pp. 341.

Wolaver, B. D., Sharp, J. M., Rodriguez, J. M. 2006. Gravity geophysical analysis of spring locations in a karstic desert basin, Cuatro Cienegas Basin, Coahuila, Mexico. Gulf Coast Association of Geological Societies Transactions 56, 885-897.

Wolaver, B. D., Sharp, J. M. Jr., Rodriguez, J. M., Flores, J. C. I., 2008. Delineation of Regional Arid Karstic Aquifers: An Integrative Data Approach. Groundwater 46,396-413.

Wolaver, B. D., Crossey, L. J., Karlstrom, K. E., Banner, J. L., Cardenas, M. B., GutiérrezOjeda, C., Sharp, J. M. Jr., 2013. Identifying origins of pathways for spring waters in a semiarid basin using $\mathrm{He}, \mathrm{Sr}$, and C isotopes: Cuatrociénegas Basin, Mexico. Geosphere 9, 113-125. 


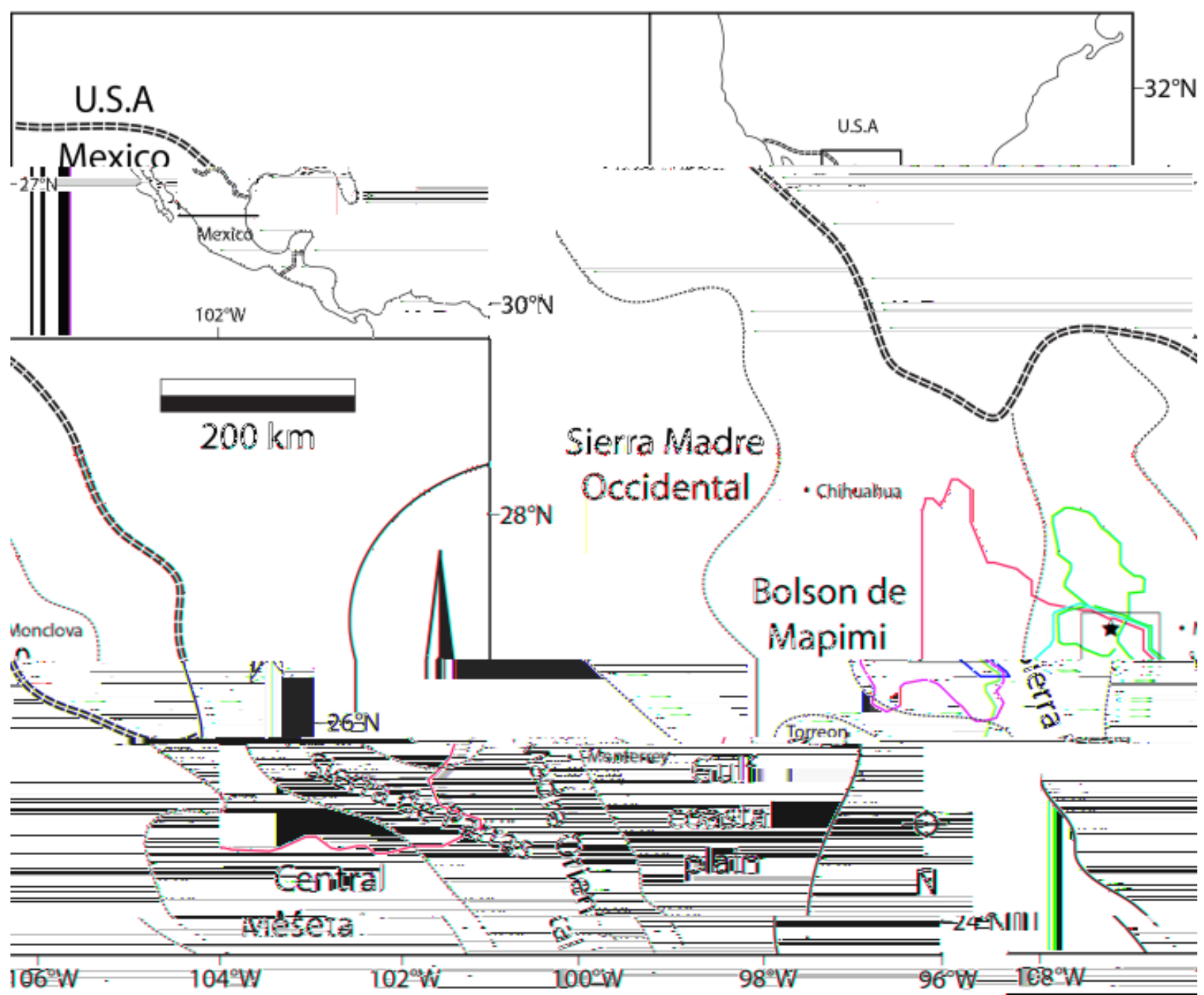

Figure 1: Location of the Cuatrociénegas Basin, NE Mexico. (a) Map shows regional geographic features, including the Sierra Madre Occidental, Bolson de Mapimi, Sierra de Parras, Sierra Madre Oriental and Gulf coastal plain. CCB groundwater catchments and recharge areas (see Wolaver et al. 2008) are also shown, including the Saca del Fuente, Santa Tecla Canal, and the Ocampo Valley local flow system (red line); Hundido, San Marcos and Sobaco Valleys (yellow line); and the $91,000 \mathrm{~km}^{2}$ regional catchment area (blue line). Black star shows the location of Cuatro Ciénegas (base map from GeoMapApp, Ryan et al. 2009). Colour reproduction on the Web only and black and white in print. 


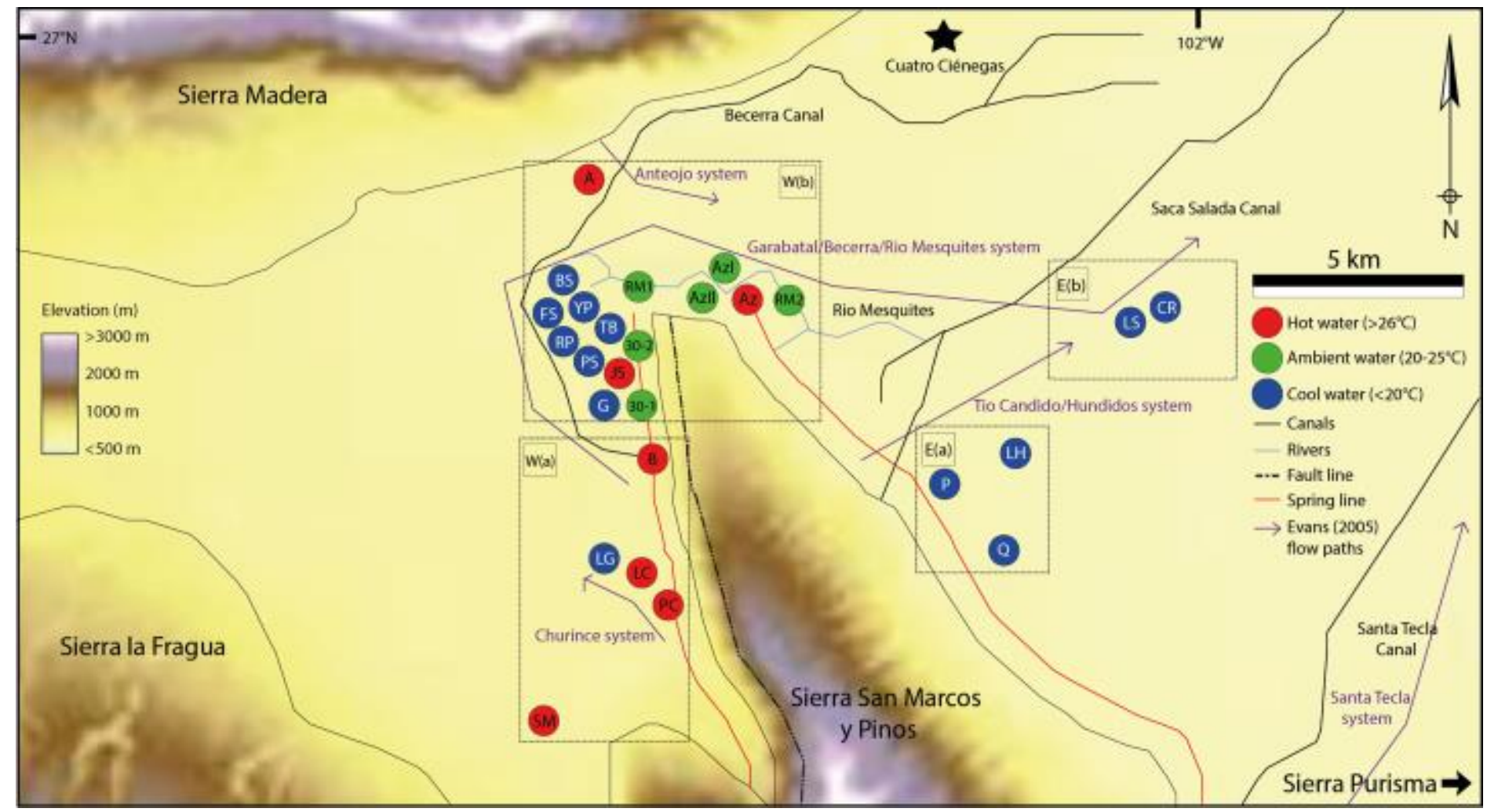

Figure 2: Water isotope sample locations, separated into four areas - W(a), W(b), E(a), E(b) - within the CCB. Sample codes are as follows: SM - San Marcos; PC - Poza Churince; LC - Laguna Churince; LG - Laguna Grande; B - Poza Becerra; G - Poza Garabatal; 30-1 - Mex 30-1; JS - Poza Juan Santos; PS - Palm Spring; RP - Rim Pond; FS - Fast Stream; TB - Poza Tierra Blanca; YP - Yucca Pond; BS - Bone Site; 30-2 - Mex 30-2; A - Poza Anteojo; RM1 - Rio Mesquites; AzII - Poza Azul II; Az I - Poza Azul I; Az - Poza Azul; RM2 - Rio Mesquites 2; Q - Poza Quintero; P - Poza Pronatura; LH - Los Hundidos; LS - Las Salinas; $\mathrm{CR}-$ Charco Rojo. Colour reproduction on the Web only and black and white in print. 


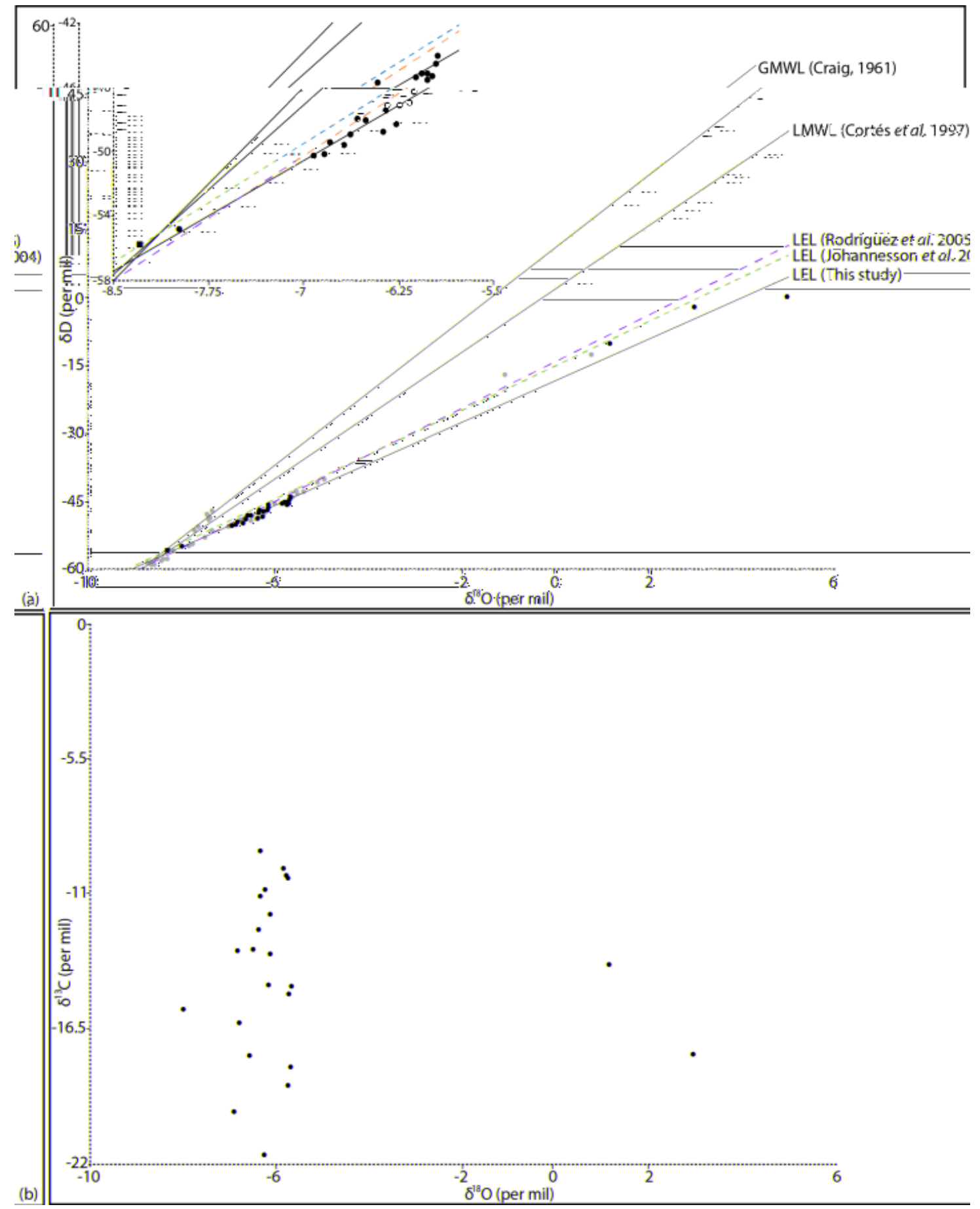

Figure 3: (a) $\delta^{18} \mathrm{O}$ and $\delta \mathrm{D}$ data for waters sampled from the CCB. The GMWL (Craig, 1961) and LMWL (Cortés $e t$ al. 1997) are displayed with CCB residual water plotting to the right as a Local Evaporation Line (LEL) $\delta \mathrm{D}=$ $4.5 \delta^{18} \mathrm{O}-1$ 19. LELs of $\delta \mathrm{D}=4.9 \delta^{18} \mathrm{O}-15.1$ (blue line) and $\delta \mathrm{D}=5.15 \delta^{18} \mathrm{O}-14.2$ (orange line) from Johannesson $e t$ al. (2004) and Rodirguez et al. (2005) respectively, are also shown. Grey dots represent CCB water samples from Rodriguez et al. (2005) for comparative purposes. The inset shows the main cluster of data points in more detail. Black square denotes seasonally weighted groundwater, indicative of precipitation (Wassenaar et al. 2009). (b) $\delta^{18} \mathrm{O}$ and $\delta^{13} \mathrm{C}_{\mathrm{TDIC}}$ data for waters sampled from the CCB. Colour reproduction on the Web only and black and white 